Stevenson, J. P. (1959). J. gen. Microbiol. 21, 366-370

\title{
A Note on the Genus Aeromonas
}

\author{
By J. P. STEVENSON \\ Department of Zoology, University College, London
}

SUMMARY: Previous workers have shown that the flagellation of certain bacteria is variable, becoming lateral or polar according to age and conditions of culture. In view of these findings, and because of the morphological and biochemical similarity of the organisms, Lysenko (1958) has equated Pseudomonas noctuarum with Serratia marcescens. It is now suggested that Pseudomonas noctuarum would be better placed in the genus Aeromonas, and that it is similar to an organism provisionally named $A$. margarita. It is further suggested that all members of the genus Aeromonas could be regarded as non-chromogenic species of the genus Serratia.

Investigation of an epizootic disease which affected laboratory stocks of the desert locust Schistocerca gregaria Forsk., resulted in the isolation of a Gramnegative organism which was subsequently shown to be the aetiological agent of the disease (Stevenson, 1958). This organism, initially thought to be a paracolon bacillus (Stevenson, 1954), was later allocated to the group Aeromonas, and provisionally labelled $\boldsymbol{A}$. margarita. Recent work by Lysenko (1958) raised doubts regarding both the taxonomic propriety of this classification and the validity of the genus Aeromonas. This paper re-examines Lysenko's classification of Bacillus noctuarum White in relation to A. margarita and the genus Aeromonas as a whole.

\section{METHODS}

Organisms used. Strains SL10a and SL11a of Aeromonas margarita isolated in this laboratory from diseased locusts. Strain 006 of Pseudomonas noctuarum (Serratia marcescens), from The Laboratory of Insect Pathology, Prague, Czechoslovakia. A strain of Serratia marcescens from the London School of Hygiene and Tropical Medicine.

Motility was determined by microscopic examination of hanging-drop preparations after culture in nutrient broth for 2,4 and $24 \mathrm{hr}$. at $37^{\circ}$.

Sugar fermentations. Cultures were incubated at $37^{\circ}$ in peptone water containing $1.0 \%(\mathrm{w} / \mathrm{v})$ of the 'sugar', using Andrade's indicator $(1.0 \%$ acid fuchsin) for the detection of acid production, and Durham tubes for the collection of gas. Examinations were made after 24 and $48 \mathrm{hr}$. and 5, 10 and 21 days.

Hydrogen sulphide production. Blackening of filter-paper strips, soaked in lead acetate and suspended above nutrient broth enriched with cysteine, was taken to indicate $\mathrm{H}_{2} \mathrm{~S}$ production. Cultures were incubated at $37^{\circ}$ for a maximum of 10 days.

Indole formation. Cultures were incubated in peptone water for 5 days at $37^{\circ}$ and tested with Böhmes' reagents. 
Urease production was tested on Christensen's (1946) urea agar slopes incubated at $37^{\circ}$ for 5 days. A red coloration of the medium was considered to indicate a positive reaction.

Phenylalanine and malonate tests. The medium and methods of Shaw \& Clarke (1955) were used.

Gelatin liquefaction was examined at $4^{\circ}$ after incubation in nutrient gelatin for 5 days at $37^{\circ}$.

Citrate utilization was tested by inoculating three successive subcultures in Koser's citrate with the tip of a straight wire, and incubating at $37^{\circ}$.

Butanediol production. The organisms were cultured for $48 \mathrm{hr}$. at $37^{\circ}$ in a tryptic meat digest with the addition of $1.0 \%(\mathrm{w} / \mathrm{v})$ glucose. Butanediol was estimated by Neish's (1952) method and by the method recommended by Pirt (1957).

$M R$ and VP tests. Cultures were incubated in glucose phosphate broth for 5 days at both $30^{\circ}$ and $37^{\circ}$, and tested according to the details given by Vaughn, Mitchell \& Levine (1939) and by Levine (1941). There was no difference in the results obtained at the different temperatures.

Flagella staining. Loeffler's(1889) and Zettnow's(1899) techniques were used.

\section{RESULTS}

All the organisms examined were similar in morphology. They were small Gram-negative rods varying in length from 0.8 to $3.0 \mu$, and in width from 0.8 to $1.0 \mu$. In $24 \mathrm{hr}$. cultures there was in all cases a preponderance of short, almost coccoid forms. Short rods with bulging sides and longer rods with parallel sides were also present. The ends were rounded and bipolar staining was common.

Motility was observed in hanging drop preparations of all strains, though in Pseudomonas noctuarum (Serratia marcescens) strain 006 it was apparent only after incubation at room temperature, and not in cultures incubated at $37^{\circ}$. The flagellation of Aeromonas and Serratia strains was apparently polar, though in one or two preparations observed under the light microscope, there were organisms which may have possessed peritrichate flagellation. The only strain examined for flagellation under the electron microscope was Aeromonas margarita strain SL10a; in this case all the flagellated organisms were monotrichate. The flagellation of $P$. noctuarum strain 006 was peritrichate.

The biochemical properties of the strains tested are given in Table 1, where they are compared with some of the results obtained by Lysenko (1958). It will be seen that, in general, all the organisms are biochemically similar.

\section{DISCUSSION}

Stevenson (1958) allocated the organism isolated from desert locusts to the genus Aeromonas on the grounds that it possessed polar flagella and produced butanediol from glucose. As it differed from other organisms listed in the genus, it was provisionally labelled $\boldsymbol{A}$. margarita, though it was pointed out that there are other organisms which resemble it morphologically and in some 
respects biochemically; these are Bacillus sphingidis White $(1923 a), B$. noctuarum White $(1923 b)$ and $B$. leptinotarsae White $(1928,1935)$. These bacilli, though no doubt properly placed in the genus Bacillus at the time of their isolation, are now more appropriately placed in the family Pseudomonadaceae, since they are Gram-negative rods with polar flagellation.

Weiser \& Lysenko (1956) placed Bacillus noctuarum in the genus Pseudomonas. However, since it ferments glucose and other sugars, and since Pseudomonas by definition excludes fermentative bacteria, it would be better placed in the genus Aeromonas were it not VP-negative and therefore not a producer of butanediol (Weiser \& Lysenko, 1956). The present tests have confirmed that the organism is VP-positive (Lysenko, 1958). In all probability,

Table 1. Biochemical reactions of certain strains of Serratia marcescens, Pseudomonas noctuarum and Aeromonas margarita

\begin{tabular}{|c|c|c|c|c|c|c|}
\hline \multirow[b]{2}{*}{ Strain } & \multicolumn{2}{|c|}{ S. marcescens } & \multicolumn{2}{|c|}{ P. noctuarum } & \multicolumn{2}{|c|}{ A. margarita } \\
\hline & Lko. & Stn. & $\begin{array}{r}\text { Lko. } \\
006\end{array}$ & $\begin{array}{c}\text { Stn. } \\
006\end{array}$ & $\begin{array}{l}\text { Stn. } \\
\text { SL10a }\end{array}$ & $\begin{array}{l}\text { Stn. } \\
\text { SL } 11\end{array}$ \\
\hline Motility & + & + & + & + & + & + \\
\hline Glucose & d & $\mathbf{A G}$ & (G) & $\mathbf{A G}$ & $\mathbf{A G}$ & AG \\
\hline Mannitol & AO & $\mathbf{A G}$ & AÓ & $\mathbf{A G}$ & $\mathbf{A G}$ & Ag \\
\hline Adonitol & d & nt. & - & nt. & nt. & nt. \\
\hline Dulcitol & - & - & - & - & - & - \\
\hline Lactose & $x$ & - & (A) 0 & - & - & - \\
\hline Sucrose & AO & AG & AÓ & $\mathbf{A G}$ & $\mathbf{A}$ & $\mathbf{A}$ \\
\hline Maltose & AO & AG & (A)O & Ag & $\mathbf{A}$ & $\mathbf{A}$ \\
\hline Salicin & AO & AG & ÁO & $\mathbf{A g}$ & $\mathbf{A}$ & $\mathbf{A}$ \\
\hline Inositol & do & nt. & (A) 0 & nt. & nt. & nt. \\
\hline Glycerol & nt. & A & $\mathbf{A} \mathbf{G}$ & $\mathbf{A G}$ & $\mathbf{A}$ & $\mathbf{A}$ \\
\hline Gelatin & + & + & + & + & + & + \\
\hline $\mathrm{H}_{2} \mathrm{~S}$ & $x$ & + & - & + & + & + \\
\hline Urease & $x$ & nt. & $(+)$ & nt. & - & - \\
\hline Indole & - & - & - & - & - & - \\
\hline MR & - & - & - & - & - & - \\
\hline VP & + & + & + & + & + & + \\
\hline Citrates & + & + & $(+)$ & + & + & + \\
\hline Malonate & - & - & - & - & - & - \\
\hline Phenylalanine & - & - & - & - & - & - \\
\hline
\end{tabular}

$+=$ positive $;-=$ negative; $A=$ acid produced; $\mathbf{G}=$ gas produced $; g=$ small quan tity of gas produced; $0=$ gas production not tested; $\times=$ indeterminate and delayed reaction; $d=$ mutative character $(+$ or -$) ;()=$ delayed action; nt. $=$ not tested. Lko. =results obtained by Lysenko (1958); Stn. = results in present paper.

therefore, it will produce butanediol and could be an aeromonad. Lysenko (1958), however, allocated it to the genus Serratia, and the present work confirms his opinion that strains of Serratia tested are, apart from chromogenesis, very similar to Lysenko's strain of $\boldsymbol{P}$. noctuarum (=Bacillus noctuarum). In addition, strains of Aeromonas margarita are morphologically and biochemically very similar to $P$. noctuarum and to $S$. marcescens.

These findings bring into question the validity of the genus Aeromonas. First proposed by Kluyver \& van Niel (1986) for the bacterium previously known as Aerobacter liquefasciens (Beijerinck, 1900), the genus was further 
studied by Miles \& Miles (1951) who came to the conclusion that if the production of butanediol from the fermentation of glucose was a stable character in an otherwise homogeneous group, the genus Aeromonas should be accepted. Stanier (1953) confirmed that $\boldsymbol{A}$. hydrophila carried out a butanediol fermentation similar to that of $A$. aerogenes and concurred in its inclusion in the genus Aeromonas. The editors of Bergey's Manual, 7 th edition (1957), list only four members of the genus, but since the preparation of that book, Pivnick \& Sabina (1957) have re-examined Pseudomonas formicans, isolated by Crawford (1954) from soluble oil emulsions, and have concluded that this organism too, should be included in the genus Aeromonas.

An examination of the flagellation of Aeromonas margarita leaves no doubt that most of the individuals are mono- or lopho-trichate. However, as pointed out by Lysenko (1958) and Stevenson (1958), the work of Leifson (1951), Leifson \& Hugh (1953), Sneath (1956) and others leads to the view that flagellation in the genera Aeromonas and Serratia may vary according to conditions of culture. Breed (1957) expressed the opinion that such variations have little taxonomic significance, the flagellation of some species having undergone a retrogressive specialization, the organisms becoming primarily dependent on one flagellum as their chief methods of locomotion. Breed said: 'This apparently intermediate type of flagellation seems to be a comparatively recent development...', but produced no evidence for this hypothesis. It may not be so much a recent development, as one that has been recently investigated.

In view of the similarities between the species of Aeromonas and Serratia, together with the changeable character of the flagellation, it is here proposed that the organism provisionally labelled $A$. margarita is in reality a nonchromogenic strain of $S$. marcescens. Further, it is suggested that all members of the genus Aeromonas are unpigmented members of the genus Serratia. Obviously, it would be necessary to carry out serological or other studies before such a conclusion could be substantiated; but if it were, it would assist, at least in some degree, to simplify the complicated taxonomy of the Gramnegative bacteria.

The author's thanks are due to Professor Wilson Smith and Dr G. Belyavin for much helpful advice; to Drs H. B. Donald and R. Valentine for electron microscopy; and to Dr S. J. Pirt for butanediol estimations.

\section{REFERENCES}

Beijerinck, M. W. (1900). Schwefelwasserstoffbildung in den Stadtgräben und Aufstellung der GattungAerobacter. Zbl. Bakt. (Abt. 2), 6, 193.

Bergey's Manual of Determinative Bacteriology (1957). 7th edn. Edited by R. S. Breed, E. G. D. Murray \& N. R. Smith; London: Baillière, Tindall and Cox.

BreEd, R. S. (1957). In Bergey's Manual of Determinative Bacteriology: Considerations influencing classification. 7th ed., p. 11. Edited by R. S. Breed, E. G. D. Murray \& N. R. Smith. London: Baillière, Tindall and Cox. 
Crawford, I. P. (1954). A new fermentative pseudomonad Pseudomonas formicans n.sp. J. Bact. 68, 734 .

Christensen, W. B. (1946). Urea decomposition as a means of differentiating Proteus and Paracolon cultures from each other and from Salmonella and Shigella types. J. Bact. 52, 461.

KuUYver, A. J. \& VAN Niex, C. B. (1936). Prospects for a natural system of classification of bacteria. Zbl. Bakt. (Abt. 2), 94, 369.

LEIFson, E. (1951). Staining, shape and arrangement of bacterial flagella. J. Bact. 62,377 .

Leirson, E. \& HUGH, R. (1953). Variation in shape and arrangement of bacterial flagella. J. Bact. 65, 263 .

LEvine, M. (1941). Determination and characterisation of coliform bacteria from chlorinated waters. Amer. J. publ. Hlth, 31, 351.

LoEfFler, F. (1889). Eine Neue Methode zum Färben der Mikroorganismen im besonderen ihrer Wimperhaare und Geisseln. Zbl. Balct. (Abt. 1), 6, 209.

Lysenko, O. (1958). Contribution to the taxonomy of Coccobacillus acridiorum d'Herelle. Folia Biol. Prague, 6, 342.

Mrues, E. M. \& Mrues, A. A. (1951). The identity of Proteus hydrophilus and Proteus melanovogenes and their relation to the genus Aeromonas. J. gen. Microbiol. 5, 298.

Neish, A. C. (1952). Analytical Methods for Bacterial Fermentations. Report National Research Council of Canada, no. 46-8-3, 2nd Revision. N.R.C. no. 2952.

Pirt, S. J. (1957). Oxygen requirement of growing cultures of an Aerobacter species determined by means of the continuous culture technique. J. gen. Microbiol. 16, 59.

Prvnick, H. \& Sabina, L. R. (1957). Studies of Aeromonas formicans Crawford comb. nov., from soluble oil emulsions. J. Bact. 73, 247.

Shaw, C. \& Crarke, P. H. (1955). Biochemical classification of Proteus and Providence cultures. J. gen. Microbiol. 13, 155.

SNEATH, P. H. A. (1956). The change from polar to peritrichous flagellation in Chromobacterium spp. J. gen. Microbiol. 15, 99.

Stanier, R. Y. (1953). A note on the taxonomy of Proteus hydrophilus. J. Bact. 46, 213.

Stevenson, J. P. (1954). An epizootic among laboratory stocks of the desert locust, Schistocerca gregaria Forsk. Nature, Lond. 174, 222.

Stevenson, J. P. (1958). A study of the microbiology of an insect infection. Thesis, University of London.

Vaughn, R., Mitchell, N. B. \& Levine, M. (1939). The Voges-Proskauer and methyl-red reactions in the coli-aerogenes group. J. Amer. Wat. Whs Ass. 31, 998.

WeIser, J. \& Lysenko, O. (1956). Septikemie bource morusoveho. Mikrobiologie, $1,216$.

White, G. F. (1923a). Hornworm septicaemia. J. agric. Res. 26, 477.

WhITE, G. F. $(1923 b)$. Cutworm septicaemia. J. agric. Res. 26, 487.

White, G. F. (1928). Potato beetle septicaemia, with a proposal of a new species of bacterium. Proc. ent. Soc. Wash. 30, 71.

White, G. F. (1935). Potato beetle septicaemia. J. agric. Res. 51, 223.

ZETTNOw. (1899). Uther Geisselfärbung bei Bakterien. Z. Hyg. InfektKr. 30, 95. 